\title{
Waqf for Socio-Economic Development: A Perspective of Ibn Khaldun*
}

\section{Sosyo-Ekonomik Kalkınma lçin Vakıf: Ibn Haldun Perspektifi}

\author{
(D) Lisa Listiana(1), (D) Syed Musa Alhabshi(2), \\ (i) Agastya Widhi Harjunadhi(3) \\ $(1,2)$ IIUM Institute of Islamic Banking and Finance, International Islamic University Malaysia \\ (3) Waqf Center for Indonesian Development and Studies (WaCIDS), Indonesia \\ (1)lisa.listiana@yahoo.com, (2)syedmusa@iium.edu.my, (3)agastya@wacids.id
}

Received: May 5, 2019 Accepted: October 13, 2019 Published: January 15, 2020

\begin{abstract}
While waqf past significant contribution towards the welfare of society has been acknowledged, it is believed that waqf has potential to be the icon and esteemed institution to establish Islamic civilization and promote socio economic justice in this contemporary era. While more studies on waqf have been conducted, it is apparent that Western perspective dominates the discussion. Less literatures from well-known Muslim scholar is explored to gain the insight for waqf development. As such, with the spirit for waqf revival, this current study is going to fill this gap by exploring and relating to the perspective of Ibn Khaldun. Firstly, this paper is going to elaborate the perspective of Ibn Khaldun on the role of the State for socio-economic development. Secondly, it will elaborate the Ibn Khaldun's perspective on how to promote moral values that warrant sustainable and fair environment in the society. Based on his perspectives, a recommended practice is proposed to promote waqf for socio-economic development. This study represents the pioneer work that attempts to elaborate waqf and Ibn Khaldun's perspective to promote sustainable socio-economic development.
\end{abstract}

Keywords: Ibn Khaldun, Moral, Socio-Economic Development, State, Waqf

Öz: Vakıf geçmişinin toplumun refahı üzerinde önemli katkısı kabul edilirken, vakfın bu çağdaş dönemde İslam medeniyetini kurmak ve sosyo-ekonomik adaleti teşvik etmek adına bir simge ve

ORC-ID: L. Listiana 0000-0001-7049-8017 Syed Musa Alhabshi 0000-0001-8274-9944 Agastya Widhi Harjunadhi 0000-0001-6684-8862

"This article is a review of the paper presented at the "5th International Ibn Khaldun Symposium" organized on 27-28 April 2019 in Istanbul. 
saygın bir kurum olma potansiyeline sahip olduğuna inanılmaktadır. Vakıf üzerinde çok fazla çalışma yapılmasına rağmen, Batı perspektifinin tartışmaya hâkim olduğu açıktır. Vakıf gelişsimi ile ilgili iç görü kazanmak için tanınmış Müs/üman âlimlerden ise daha az çalışma tetkik edilmiştir. Haddi zatında bu çalışma vakfın dirilişi için bu tutum ile ibn Haldun'un perspektifini keşfederek ve onunla iliş̧kilendirerek bu boşluğu dolduracaktır. Illk olarak, bu makale ibn Haldun'un sosyoekonomik kalkınma için Devletin rolü konusundaki perspektifi üzerinde duracaktır. İinci olarak, ibn Haldun'un toplumda sürdürülebilir ve adil ortamı garanti eden ahlaki değerlerin nasıl teşvik edileceğine ilişskin bakış açısını ele alacaktır. Onun bakış açısına dayanarak, sosyo-ekonomik kalkınma için vakfın teşvik edilmesi adına önerilen bir uygulama teklif edilmektedir. Bu çalışma sürdürülebilir sosyo-ekonomik kalkınmayı teşvik etmek için vakıf ve Ibn Haldun'un bakış açısını detaylı bir şekilde ele alma girişiminde bulunan öncü çalışmaları temsil etmektedir.

Anahtar Kelimeler: Ibn Haldun, Ahlak, Sosyo-Ekonomik Kalkınma, Devlet, Vakıf

\section{Introduction}

Within last decades, more studies related to waqf have been conducted with broader scope and perspectives (IWB, 2016; Nasir, 2017). Initially, researches on waqf area were more relevant to fiqh, law, or historical aspect. Different situations can be observed as currently more research are being conducted from economic dimensions. There are proposal to synergize between waqf and economic development, Islamic finance, Islamic financial institutions, zakat, and etc (Ascarya, Husman, \& Tanjung, 2018; Sadeq, 2002; Shirazi, 2014). In addition, waqf is also discussed within the contemporary issues such as Sustainable Development Goals (SDGs) and blockchain technology (Abdullah, 2018 ; Rashid, 2018).

Within its broader scope, it is apparent that waqf is discussed and explored from the Western perspective. Even Waqf Core Principles (WCPs) that was developed by the International Working Group on Waqf are mainly according to the Basel Core Principles that origin from conventional financial services. Whereas those progress and development need to be examined, due to the lack reference to literatures from wellknown Muslim scholar to gain the insight for waqf development. As such, with the spirit for waqf revival, this current study is going to fill this gap by exploring and relating to the perspective of Ibn Khaldun view on waqf. In many literatures, Ibn Khaldun (1332$1406 \mathrm{M})$ is mentioned as the fourteenth century Muslim thinker, economist and father of sociology who has been acknowledged by his intellectual legacy (Chapra, 2007; Ismail, Ramli, Yaacob, Tasrif, \& No, 2014; Karatas, 2018). It is expected that current study may contribute to the body of knowledge and offer value laden lessons learned for present waqf sector. 
Karatas (2006) mentioned that the ideas given by Ibn Khaldun are still relevant with current context. As such, interpretation of Ibn Khaldun's work offered by contemporary scholars complements the review of the book Mukaddimah of Ibn Khaldun to explore his perspectives that may be relevant to waqf context. This paper is divided into four sections. The first section is introduction. Second section review the existing literatures related to waqf and socio-economic development, especially from Islamic perspective. Later, the stance of Ibn Khaldun with regard to the role of state and the moral teachings to promote waqf for socio-economic development are elaborated before conclusion in the last section.

\section{Waqf and Socio-Economic Development}

\subsection{Waqf: Past and Present}

According to AAOIFI (2015), waqf is "making a property invulnerable to any disposition that leads to transfer of ownership and donating the usufruct of that property to the beneficiaries". Initially waqf in Islamic civilization was practiced by Rasulullah (peace be upon him) and the companions. Although no explicit "waqf" terminology can be found in Quran as the main Islamic jurisprudence, its practice is being recommended in Shariah (AAOIFI, 2015; Abbasi, 2012). In principle waqf assets should be sustained while its benefit flows in perpetuity to the waqf beneficiaries (mauquf alayhs). In addition, AAOIFI (2015) noted that all of their activities need to be in accordance with Shariah principles.

In the past, Çizakça (2016) noted that waqf was normally created by rich single waqf giver (waqif) by giving fixed assets in form of land, building, or properties. At that time, they could easily appoint either other people or themselves to be the responsible party to manage the waqf assets, called as nazhir or mutawalli. Currently, innovative waqf assets are collectively contributed by waqifs ( $\mathrm{H}$. Ahmed, 2018) in the form of cash. Collective contributions in the form of cash waqf allows for flexibility and encourage more participants in Indonesia, Malaysia, Singapore, and Turkey as it is permissible by law.

Within the last decades, more studies and initiatives to revive the waqf sector are observed. While significance of waqf to the society has been acknowledged in the past, it is believed that waqf has the potential to contribute positively for the society and address the current global issues like poverty and inequality (Cizakca, 1998; Sadeq, 2002). While prevalent capitalist economic system encourages people to accumulate individual wealth, waqf on the other hand, promotes social well-being and care for others. Waqf scheme enables retail or individual donors to collectively accumulate funds for productive investment. Ibn Khaldun mentioned in the Mukaddimah that wealth in 
form of estates and farms need a progressive and persistent wealth accumulation process. He mentioned that "The accumulation of numerous estates and farms by the inhabitants of towns and cities does not come all at once and not at one time. No one person would have enough wealth to acquire limitless (real) property..." (Rosenthal, 1958, p. 463). According to this proposition, waqf may become alternative for sources of funding on businesses that are required by human being, especially by Muslim ummah to secure their independency.

Saptono (2018) stressed that waqf represents activities that enables wealth allocation and distribution. Technically, the waqif will give the waqf assets to the selected nazhir. Then the nazhir will manage and develop waqf assets so that there will be a perpetuity benefit to be distributed to the mauquf alayh. The mauquf alayh can be either public, family, or combination of both according to the intention of waqif, as stated in the waqf deed. Therefore, it is mentioned to offer justice to more people (Abdul-Karim, 2011). In many literatures, waqf is proposed to become the alternate solutions of conventional financial and micro-financing systems (Mohammad, 2015). Waqf is expected to be an economic institution, property, activity or fund to promote socio-economic development.

\subsection{Socio-Economic Development from Islamic Perspective}

Initially, economic growth dominates the discussion of economic development in the past. As the time goes by, more studies acknowledged that economic growth itself is not sufficient to represent the meaning of economic development. Ismail et al (2014) and Mirakhor \& Askari (2010) among others, noted such changes. Sadeq (1987) asserted that from Islamic perspective, economic development covers both material and nonmaterial improvement to secure both temporal life in this world and permanent stages of human beings in the hereafter. As such, he noted that the index of economic development need to be based on "economic growth, equity distribution of income and wealth, and a healthy and congenial social environment of Islamic norms and values" (Sadeq, 1987, p. 37). Socio-economic development need to be aligned with maqasid al shariah with aims to ensure the human wellbeing (Ismail et al., 2014; Sadeq, 1987).

Chapra (2007) interpreted from Ibn Khaldun's Mukaddimah that "the development or decline of an economy or society does not depend on any one factor, but rather on the interaction of moral, social, economic, political and historical, factors over a long period of time". Sadeq (1987) noted that greed and lack of ethical values are mentioned to be the underpinning reason that cause financial crisis. Mohammad (2010, p. 1) noted that "Overconsumption, corruption i.e. disregard for moral values, and the greed for wealth are recognised as the indicators of the fall of civilisations which are proxied to be the 
indicators of unsustainable development. "According to his understanding on principles of Ibn Khaldun, a) collective authority in form of state, b) the rules, regulations, and institution to enforce them, c) people, d) wealth and development, e) justice, f) moral legitimacy are mandatory to enable strong economic development. These represent factors that may influence the rise and fall of civilization.

\section{Relevant Ibn Khaldun's Perspectives to Waqf Sector}

\subsection{Promoting Societies' Well-Being Through Waqf: Analysis on Role of State}

In waqf sector, to date, two different arguments with regard to the role of state remains. Malik (2016) and Cizakca (2018) argued that waqf sector need to be independent from the state. This argument was based on historical experience as the government misused the waqf assets that brought down their significance. On the other hand, state based authority is expected to exist to support the development of waqf sector in the country (Kahf, 2015; Rashid, 2018).

According to the Mukaddimah of Ibn Khaldun, Chapra (2007) noted that "Ibn Khaldun viewed the state to be neither a laissez faire state nor a totalitarian state. It is rather a state which ensures the prevalence of the Shariah and serves as an instrument for accelerating human development and well-being". Here, clearly that government is expected to play public interest welfare role with the assigned or elected authority. In waqf context, as Ibn Khaldun argued that there is no need for government's involvement in trade, production and commercial affairs, the role of the state needs to be as authority (regulator/ruler) only. To Ibn Khaldun, state need to establish laws and regulations to enable conducive economic activities. In addition, Ibn Khaldun predicted that involvement in such activities may decrease the economic surplus and cause countries decline (Karatas, 2006).

However currently in some countries, waqf authorities assuming both regulator and administrator roles at the same time, while there are some other private waqf institutions which play administrator role only. Given the dual state role, it seems that the state competes with private sector, but with non-level playing position and authority on waqf activities. It is expected that state involvement as waqf administrator may cause control issues due to absence of segregation of duties (U. Ahmed, 2013). Even in some other countries, waqf authority represents the only regulator and administrator at the same time on waqf matters. In this kind of situation, people in the society are apparently do not have alternative institutions in the country to give their waqf. As such, due to the state's bureaucracy, people may resist and be discouraged to create any new waqf (Çizakça, 2016). 
In addition to that, waqf authority needs to implement good governance to avoid any corruption or misappropriation of authority as it happened in the past. Chapra (2007) noted that Ibn Khaldun required the state to be both accountable and transparent. As elaborated, "Ibn Khaldun emphasized and characterized the role of the state in development as good governance, responsible for its permissive to participate in decision making according to the principle of shura" (Chapra, 2007; Mohammad, 2010). Take a lesson from his propositions on the role of state in waqf context, there is an urgency for waqf authorities to make necessary changes to develop waqf sector in their respective country.

\subsubsection{Waqf Habit and Role of State}

In Mukaddimah, Ibn Khaldun (2015, p. 690) mentioned that habits can influence and shape human characters. Therefore, good habits need to be encouraged into an ecosystem or habitat. In case of waqf, waqf literacy need to be spread so that more people understand its urgency and its goodness. Sufficient effort needs to be conducted to address this kind of misconception about waqf. In the grassroot, many Muslims think that waqf is limited to the tangible assets such as land and building, hence can only be done by the rich people. While in fact, everybody is eligible to create waqf.

When Muslim have proper and correct understanding the importance and benefit of waqf both in this world and the hereafter, it is expected that they will have strong motivation to create many other waqf. Moreover, it can be noted that there is no companion left without established waqf (Abdullah, 2015). And since the given waqf assets will no longer belong to the waqif once it is declared as waqf, practising waqf may train people become more sincere, hence better characters. The more people become waqif, the better for the state as "public spending contributes to the welfare and prosperity of people which in turn strengthens the state" (Mohammad, 2010, p. 11).

Practical wisdom of waqf literacy may be promoted through education and by allocating sufficient resources to encourage public awareness waqf campaign. To this end, state can take a role by providing sufficient resources and supportive regulations. Waqf sector warrants for sufficient budget as it deserved mentioned to have huge potential to promote justice in terms of socio-economic dimension (Çizakça, 2000). Other than resources in form of adequate budget, the state may take an important role by ensuring that only competent and skilful human resources involve in the waqf authority. This action is important since quality of human resources within the waqf authority may influence its effectiveness. This aligns with the stance of Ibn Khaldun who encouraged the state to pay attention to the welfare of people (Chapra, 2007; Mohammad, 2010). In 
addition, government or people with authority may provide good role model by creating waqf infrastructure and incentives. In the past, waqf that was established by Rasullullah (pbuh) encouraged his companions to do waqf as well (Abbasi, 2012).

\subsubsection{State Policies for Professional Nazhir}

In parallel while the waqf habit that is being promoted, there is necessity to ensure the quality of professional nazhir. In his book, Ibn Khaldun asserted that skilful and competent people need to be placed in every field of work. Waqf need to be within management of such people to fulfil its objective and maintain its characteristics. In nature, nazhir belongs to service-based occupations (servants) that according to Ibn Khaldun (2015, p. 691) can be categorized into four. "He may be capable of doing what he has to do, and trustworthy with regard to the things that come into his hands. Or, he may be the opposite in both respects, that is, he may be neither capable nor trustworthy. Or, he may be the opposite in one respect only, that is, he may be capable and not trustworthy, or trustworthy and not capable" (Rosenthal, 1958). The first represents those with high value (salary), in contrast with the second which is not expected. He mentioned that when both characters cannot be secured in once, the capable is preferred rather than the trusted only. In summary, it can be illustrated in figure 3.1

\begin{tabular}{|l|l|}
\hline Capable and Trust worthy & Capable but not trustworthy \\
\hline Trustworthy but not capable & Neither trustworthy not capable \\
\hline
\end{tabular}

Figure 3.1 Categorization of Service-Based Occupations

Developed from Mukaddimmah of Ibn Khaldun (Rosenthal, 1958)

Professional nazhir is expected to have proper capability (competency) and trustworthiness (integrity) (Mohsin et al., 2016), so that able to manage the waqf assets in their best interest. As an effort to call people's interest to become nazhir, proper appreciation and compensation need to be given. Ibn Khaldun (2015) asserted that the more demand on particular livelihood, the higher the value is. Currently, many nazhirs are voluntary and do not enforced to any specific qualifications or certification. Sometimes, they come from religion background rather than business, economic, or professional background. With this proposition, demand for professional nazhirs need to be created by the authority. Practically, it is necessary for the state to regulate that waqf institutions can only be managed by professional nazhirs, those who have passed particular training or certification to ensure sufficient knowledge and competencies in managing and developing the waqf assets properly. 


\subsubsection{Options for Investment of Waqf Assets}

Ibn Khaldun (2015) acknowledged that high demand business is more promising to provide more value and benefits. According to him, maintaining quality investments is a prerequisite to sustain in a business. Apply his propositions in waqf context, the investment of waqf assets need to be allocated in high demand business with proper and effective quality control towards its realising productive outcome. Practical wisdom suggests the collected cash waqf need to be invested in way to enable sustainability of those assets while also producing benefit for the mauquf alayh in perpetuity. As such, a number of investment options may be differed between each waqf assets. Theoretically, when there is no specific requirement given by the waqif, then nazhir may invest the most productive waqf assets in the best interest of the beneficiaries.

Currently, when choosing investment, many people consider investing the waqf asset in real estate and rental business. The reason is normally due to its easy scheme and simplicity. However, it should be noted that demand of products from this kind of business is limited to specific people who are having sufficient fund, business or other interest for office or space. On the other hand, consumer goods business, agriculture, or livestock business may become more appropriate for waqf investment in the long run. These kinds of businesses are high demand in nature due to its ability to fulfil basic needs of people in majority. In principle, investment of waqf assets need to consider the local wisdom and available resources and demand in their surrounding area. As such, the potential high value in demand may secure the investment.

\subsection{Moral Values for Sustainable Socio-Economic Development: Proposal for Waqf Context}

From his work, it can be noted that Ibn Khaldun acknowledged the central roles of human being in civilization (Chapra, 2007; Khaldun, 2015). Moral value and justice are mentioned to be clearly matters to the rise and fall of civilization. According to Ibn Khaldun, immorality and injustice are recognized as the indicators of unsustainable development that may cause the fall of nations (Ismail et al., 2014). As such, sufficient resources and efforts need to be allocated to improve and promote both moral and justice among people in the society.

Chapra (2007) noted from existing literatures that moral degeneration represents among the important factor which led the decline of Muslim civilization. Ibn Khaldun acknowledged that concentration in luxury custom and spending lead to corruption and wastage (İsmail \& Jaafar, 2017, p. 27; Rosenthal, 1958, p. 469) hence need to be avoided. In waqf context, Rashid $(2014,2018)$ and Çizakça (2016) stressed that significant 
decline of waqf contribution in the past was also caused by this anomaly. Therefore, to avoid such failure, there is an urgent need to improve the moral and ethical value of people in the society. Educating Muslim to embrace Islamic teaching in their daily life should be an option.

According to the extant literatures, Ismail et al (2014) noted that religiosity significantly influence economic development. Islam, as the revealed religion had a significant effect on harmonic balanced economic development in history of Muslim civilizations (Omar, Hussin, \& GH, 2015, p. 99). Primarily Islamic teaching alleviate human belief, practice and ethics as akhlaq. In many occasions, Muslim need to be reminded of their amanah as servants of Allah swt and vicegerent of the earth. As mentioned by Maniam (2016), the Islamic values and principles can be instilled and cultivated in the educational system. In addition to that, character and personal development may also be emphasized as subject to be taught. By embracing the values and implementing these approaches, amore cultured, and caring society is developed to be sensitive to the environment. These values are important due to the nature of human being as social creatures, hence cannot sustain by his/herself. Ibnu Khaldun stressed this point in his book, as noted by Mohammad (2010, p. 8) that "Ibn Khaldun recognises civilisation to consist of both organisation and cooperation".

In substance, Islam encourages the economic development which is underlined with the application of morality, ethics, and social justice, equitable and fair development" (Ismail et al., 2014). Good morality needs to be infused to each Muslim in order to promote their awareness on the requirement of integrity and competency in doing every job. Relevant to this matter, Chapra (2007) elaborated pre-requisites to the Khaldunian's model attributed to the sovereign in his work.

1. The strength of the sovereign $(a /-m u l k)$ does not materialize except through the implementation of the Shariah

1.1. The Shariah cannot be implemented except by the sovereign (al-mulk)

1.1.1. The sovereign cannot gain strength except through the people (al-rija)

1.1.1.1. The people cannot be sustained except by wealth (al-mal)

1.1.1.1.1. Wealth cannot be acquired except through development (al-imarah)

1.1.1.1.1.1. Development cannot be attained except through justice ( $a /$-ad)

1.1.1.1.1.1.1. Justice is the criterion (al-mizan) by which God will evaluate mankind 1.1.1.1.1.1.1.1. The sovereign is charged with the responsibility of actualizing justice

In order to promote justice, laws and regulations need to be implemented and enforced properly. Similarly, in the waqf context which has religious value in nature, relevant laws and regulations need to be implemented properly. Necessary actions need to be taken 
for any deviation to the existing laws and regulations, so that people are being motivated to behave in the best moral and ethical value. Skill and sincerity of human being represents two main requirement to enable and promote justice in the society (Mohammad, 2010; Sadeq, 1987).

\section{Conclusion}

To summarize the Ibn Khaldun's perspectives that relevant to waqf context, these precedents that may fit with the current effort in promoting waqf for socio-economic development. Related to the role of the state, there are three. First, the state needs to act as authority (regulator/ruler) only. Second, the state needs to promote waqf habit and allocate sufficient resources to run massive campaign to spread people awareness to waqf and increase the waqf literacy in the Muslim society. Misconception on waqf assets need to be addressed. Sufficient resource allocation to develop waqf sector is required to actualize its huge potential. Third, there is urgency for the state in supporting the existence of professional nazhirs and ensuring adequate appreciation flows to them. In terms of moral value, the Islamic teaching need to be elaborated in the educational system in terms of character and personal development. It is expected that content relevant to waqf need to be included in the proposed collaboration. There should also be law enforcement towards the existing laws and regulations on waqf to encourage nazhirs' discipline. This study represents a pioneer attempt to elaborate Ibn Khaldun's perspective on waqf context to promote its contribution towards the sustainable socioeconomic development.

\section{References}

AAOIFI. (2015). Shari'ah Standard. Manama: AAOIFI.

Abbasi, M. Z. (2012). The classical Islamic Law of waqf: A concise introduction. Arab Law Quarterly, 26(2), 121-153.

Abdul-Karim, S. (2011). Contemporary Waqf Administrations and Development in Singapore;

Challenges and Prospects. In Essential Readings in Contemporary Waqf Issues. Kuala Lumpur: CERT Publications Sdn. Bhd.

Abdullah, M. (2015). A New Framework of Corporate Governance of Waqf: A Preliminary Proposal. Islam and Civilisational Renewal (ICR), 6(3).

Abdullah, M. (2018). Waqf, Sustainable Development Goals (SDGs) and maqasid al-shariah. International Journal of Social Economics, 45(1), 158-172.

Ahmed, H. (2018). Integrating Waqf \& Islamic Finance. In Global Conference on Awqaf and Endowments: Evolution, Socio-economic Impact, Management Strategies, Legal \& Governance Issues, Cash Waqf \& Country-wise Case Studies. Doha.

Ahmed, U. (2013). Developing a Waqf-Based Model for Modern Healthcare Services in Uganda. International Islamic University Malaysia. 
Ascarya, Husman, J. A., \& Tanjung, H. (2018). Designing Waqf-Based Is/amic Financial Institution Model.

Chapra, M. U. (2007). Ibn Khaldun's theory of development: Does it help explain the low performance of the present-day Muslim world? The Journal of Socio-Economics, 37(2), 836863. https://doi.org/https://doi.org/10.1016/j.socec.2006.12.051

Cizakca, M. (1998). Awqaf in history and its implications for modern Islamic economies.

Çizakça, M. (2000). A history of philanthropic foundations: The Islamic world from the seventh century to the present. Boğaziçi University Press Istanbul.

Çizakça, M. (2016). From Destruction to Restoration? Islamic Waqfs in Malaysia and Turkey. Waqf Workshop. Doha: Brill.

Çizakça, M. (2018). Waqf and Human Capital. In Global Conference on Awqaf and Endowments: Evolution, Socio-economic Impact, Management Strategies, Legal \& Governance Issues, Cash Waqf \& Country-wise Case Studies. Doha.

İsmail, A. G., \& Jaafar, A. B. (2017). Tax Rate and its Determinants: An Opinion from Ibn Khaldun. Journal of Ibn Haldun Studies, 2(1).

Ismail, A. G., Ramli, R. M., Yaacob, S. E., Tasrif, M., \& No, J. G. (2014). Ibn Khaldun's Thought on Sustainable Development. In International Conference of Global Islamic Studies.

IWB. (2016). Waqf Phenomena in Indonesia, Challenges toward Productive Waqf (Fenomena Wakaf di Indonesia, Tantangan menuju Wakaf Produktif). Jakarta: Indonesian Waqf Board.

Kahf, M. (2015). Wakaf Islam (A/ Waqf A/ Islamic: Its Historical Growth, Development, and Management) (Bahasa (Tr). Jakarta: Indonesian Waqf Board (Badan Wakaf Indonesia).

Karatas, S. C. (2006). The Economic Theory of Ibn Khaldun and the Rise and Fall of Nations. Manchester: FSTC Limited.

Karatas, S. C. (2018). The Economic Theory of Ibn Khaldun and the Rise and Fall of Nations Muslim Heritage. Retrieved December 14, 2018, from http://www.muslimheritage.com/article/economic-theory-ibn-khaldun-and-rise-and-fallnations

Khaldun, I. (2015). Mukaddimah Ibnu Khaldun (Bahasa). Jakarta: Pustaka Al-Kautsar.

Malik, M. (2016). Foundations of Is/amic Governance: A Southeast Asian Perspective (Vol. 1). Taylor \& Francis.

Maniam, V. (2016). An Islamic Voice for Openness and Human Development in Education: The Relevance Of Ibn Khaldun's Ideas to Australian Teacher Education Programs Today. Postcolonial Directions in Education, 111.

Mirakhor, A., \& Askari, H. (2010). Islam and the path to human and economic development. Springer.

Mohammad, M. T. S. H. (2010). Principles of sustainable development in Ibn Khaldun's economic thought. Malaysian Journal of Real Estate, 5(1), 1-18.

Mohammad, M. T. S. H. (2015). Theoretical and trustees' perspectives on the establishment of an Islamic social (Waqf) bank. Humanomics, 37(1), 37-73. https://doi.org/10.1108/H-052013-0032

Mohsin, M. I. A., Dafterdar, H., Çizakça, M., Alhabshi, S. O., Razak, S. H. A., Sadr, S. K., ... Obaidullah, M. (2016). Financing the Development of Old Waqf Properties. Springer. 
Nasir, F. M. (2017). Bibliography and Review of Selected Waqf Literature in Indonesia: Origins, Past and Current Trends. In Global Waqf Gateway: Bridging the Waqf Agenda For Nusantara. Pekanbaru: ICWR.

Omar, W. A. W., Hussin, F., \& GH, A. A. (2015). The Empirical Effects of Islam on Economic Development in Malaysia. Research in World Economy, 6(1), 99.

Rashid, S. K. (2014). Factors Affecting the Development and Good Governance of Awqaf. In International Conference on Waqf Management: Turkish Experience. Turkey: ICWR.

Rashid, S. K. (2018). Potential of Waqf in Contemporary World. Journal of King Abdulaziz University: Is/amic Economics, 37(2), 53-69.

Rosenthal, F. (1958). The Muqaddimah (English). An Introduction to History, 3.

Sadeq, A. M. (1987). Economic development in Islam. Journal of Islamic Economics, 1(1).

Sadeq, A. M. (2002). Waqf, perpetual charity and poverty alleviation. International Journal of Social Economics, $29(1 / 2), 135-151$.

Saptono, I. T. (2018). Waqf Based Financial Institutional Design.

Shirazi, N. S. (2014). Integrating zakāt and waqf into the poverty reduction strategy of the IDB member countries. Islamic Economic Studies, 22(1), 79-108. 